\title{
An Introduction to the Life and Work of John Hughlings Jackson
}




\section{Introduction}

In 1860, physicians had no systematic procedure for diagnosing diseases of the nervous system. Even worse, they had no conceptual basis by which to organize their thinking about how the nervous system works. By 1910, they were able to diagnose neurological disease using consistent scientific principles. The development of scientific neurology is a model of how science emerges.

John Hughlings Jackson created the conceptual framework for clinical neurophysiology, the discipline that underlies diagnostic neurology. He began by establishing a consistent scientific method based on the systematic analysis of anatomy, pathology and physiology. This method revolved around his concept of the focal lesion, a concept that he refined and which became a cornerstone of bedside neurology. He recognized that focal epilepsy and focal necrosis can be viewed as reciprocal physiological processes, and concluded that somatotopic representation is found in the entire nervous system including the cortex.

Hughlings Jackson was a practising physician with little formal education in nonmedical topics. His practical framework for thinking about neurophysiology applied contemporaneous evolutionary theories to medicine. He conceived of diseases of the nervous system as a process of de-evolution, or dissolution. He came to believe that the nervous system is hierarchy of three evolutionary levels that represent, re-represent and re-rerepresent movement and sensation of the parts of the body. Higher levels suppress the function of lower levels, so that the symptoms of neurological disease are dual in nature. Negative symptoms result from the loss of function of higher levels, and positive symptoms result from the appearance of the function of previously inhibited lower levels. These emergent functions are inherently less organized, less definite and more general than the functions that are lost.

Physicians admired Hughlings Jackson during his lifetime, but his personality and the nature of his work made him invisible to the larger scientific and cultural world. The appearance of experimental and cognitive neuroscience in the twentieth century has made his ideas more widely influential, and there is every reason to think that this trend will continue.

\section{Biographical Sketch}

John Hughlings Jackson was born on 4 April 1835 at Providence Green, his father's home in Green Hammerton, ten miles northwest of the city of York. He was the youngest of five children, with three brothers and a sister. His father, Samuel Jackson, was a prosperous brewer and farmer. His mother, the former Sarah Hughlings, was the daughter of John Hughlings, an excise collector from Northowram in west Yorkshire. John Hughlings Jackson was baptised on 19 June 1835 in the Independent Chapel of Green Hammerton 


\section{Introduction}

by his great-uncle, the dissenting minister James Jackson. His mother died when he was a year old. ${ }^{1}$

He was educated at the local school in Green Hammerton, followed by stints at boarding schools in Tadcaster, in Yorkshire, and Nailsworth, in Gloucestershire. ${ }^{2}$ He attended school with his older brother Thomas, who supported and encouraged him during his childhood and for whom he retained a lifelong affection. On 20 October 1850, aged fifteen, he ended his formal education and became an apprentice to Dr William Charles Anderson and his son Tempest Anderson, prosperous physicians who lived at 23 Stonegate in York. ${ }^{3}$

After two years of working in the Anderson household, Hughlings Jackson began classes at the York Medical School, where William Anderson was a lecturer. ${ }^{4}$ The faculty, made up of local practitioners, lectured for a fee to the dozen or so students in attendance. Here he was a student of Thomas Laycock, later professor of medicine at Edinburgh, who exerted a strong influence on his career and on his medical and physiological interests. ${ }^{5}$

In order to practise general medicine in Yorkshire, he had to qualify as a surgeon and apothecary. The Apothecaries Act of 1815 required candidates for their licence to present evidence of attendance at an approved hospital, and the York County Hospital was just such an institution. The Worshipful Society of Apothecaries accepted Hughlings Jackson's training in York as a qualification for their licence, and on 10 April 1856, he presented himself at the Apothecaries Hall for examination. ${ }^{6}$ The record of this purely oral examination gives his place of residence as Green Hammerton, Yorkshire. He presented his apprenticeship indenture and a testimonial of his moral character from William Anderson, and evidence of his attendance at the required course of lectures at the York Medical School. Completing this examination successfully, he took the qualification LSA. ${ }^{7}$

In order to qualify for membership, the Royal College of Surgeons required a year's attendance on a surgical ward of a large hospital in addition to attendance at lectures. No hospital in York was acceptable to the Royal College; hence in 1855 and 1856 Hughlings Jackson walked the wards at St Bartholomew's Hospital in London. Even though he was one among many medical students, his performance attracted the attention of James Paget. ${ }^{8}$

\footnotetext{
${ }^{1}$ For biographical details, consult James Taylor's biographical memoir in John Hughlings Jackson, Neurological Fragments, London, Oxford University Press, 1925, pp. 1-26. See also Macdonald Critchley and Eileen A Critchley, John Hughlings Jackson: father of English Neurology, Oxford, Oxford University Press, 1998.

${ }^{2}$ Taylor, op. cit., note 1 above, p. 2.

${ }^{3}$ MS 8241/18, fol. 58, no. 7 in the Society of Apothecaries' Court of Examiners' Candidates' Entry Book (1855-1858), which is a microfilm of a document located in the Guildhall library, London. See also the seminal study by Samuel H Greenblatt, 'The major influences on the early life and work of John Hughlings Jackson', Bull Hist Med, 1965, 39: 346-376, pp. 347 note 3.

${ }^{4}$ J H Wetherill, 'The York Medical School', Med Hist, 1961, 5: 253-269, p. 257.

${ }^{5}$ For an overview of Laycock's life and work, see Michael Barfoot, "To ask the suffrages of the patrons": Thomas Laycock and the Edinburgh chair of medicine, 1855, London, Wellcome Institute for the History of Medicine, 1995, pp. 1-22.

${ }^{6}$ Society of Apothecaries' Court of Examiners' Candidates' Entry Book (1855-1858), op. cit., note 3 above, p. 58 , no. 7. This licence would not have allowed Hughlings Jackson to practise in the City of London or within a seven-mile radius of it. See also S W F Holloway, 'The Apothecaries' Act, 1815: a reinterpretation. Part I: The origins of the Act', Med Hist, 1966, 10: 107-29, pp. 124-125, and 'The Apothecaries' Act, 1815: a reinterpretation. Part II: The consequences of the Act', Med Hist, 1966, 10: 221-236, p. 233.

${ }^{7}$ See MS 8241/18, fol. 58, in the Society of Apothecaries' Court of Examiners' Candidates' Entry Book (18551858), op. cit., note 3 above.

8 'London Hospital. Presentation of testimonial to Dr. Hughlings Jackson, F.R.S., by Sir James Paget', Br MedJ, 1895, ii: $861-863$.
} 


\section{Introduction}

In 1856 Hughlings Jackson passed the examination of the Royal College of Surgeons, although no records remain of his performance in the examination, and took the qualification MRCS.

The qualifications of the Surgeons' College and the Apothecaries' Hall entitled him to practise as a surgeon-apothecary and, as LSA and MRCS, he could have returned to Yorkshire to seek his fortune as a general practitioner. ${ }^{9}$ His alternative was to seek further training and to qualify as a physician. He might have sought a Continental or Scottish education with the aim of taking an MD, but he took another road, one that was at once more familiar and safer. He stayed in Yorkshire.

Hughlings Jackson had other reasons for returning to Yorkshire. His father had suffered serious financial reverses, possibly by speculating in railway stock. The precise timing of Samuel Jackson's financial troubles is not clear, but in a letter dated 17 March 1854 Samuel Jackson exhorted his son John to a life of frugality in dress and custom. ${ }^{10}$ Hughlings Jackson's three brothers emigrated to New Zealand after 1856, at the same time that their father moved out of Providence Green and into a house in Green Hammerton. His father was by now not only impoverished but in failing health, which may have motivated Hughlings Jackson's return in 1856. On 9 February 1858 Samuel Jackson died; his son John was in his second year as a houseman in York.

After qualifying, he was appointed resident medical officer at the York Dispensary and spent the next three years as a house officer. Little is known of this phase of his medical training, but we do know that he endured personal reverses, beginning with the emigration of his brothers. His sister Ann, never in good health, had a stroke, and died in 1859. Thus, by the end of his house years he was left with no close family in the country. ${ }^{11}$

While he was a houseman he joined the York Medical Society, whose minute book contains his first recorded analysis of diseases of the nervous system. In this report, dated 8 January 1859, Hughlings Jackson presented cases of paralysis arising from diseases of the spine, corpus striatum and hemispheres. ${ }^{12}$ In his discussion, Hughlings Jackson referred to the ideas of Robert Bentley Todd, indicating that he was familiar with Todd's volume of lectures on paralysis and other diseases of the nervous system.

At some time between May and October 1859 Hughlings Jackson left the city of York and moved to London. ${ }^{13}$ He carried an introduction to his fellow Yorkshireman Jonathan Hutchinson, with whom he soon formed a lifelong friendship. Nearly seven years older than Hughlings Jackson, Hutchinson had followed a similar path into London medicine. In the summer of 1859 Hutchinson was a member of the medical staff at a number of London hospitals, including the Royal London Ophthalmic Hospital and the London Hospital. ${ }^{14}$

\footnotetext{
${ }^{9}$ M Jeanne Peterson, The medical profession in mid-Victorian London, Berkeley, University of California Press, 1978, p. 11.

${ }^{10}$ Critchley and Critchley, op. cit., note 1 above, pp. 29-31.

${ }^{11}$ Ibid., pp. 1-32.

${ }^{12}$ Greenblatt cites this document as being in the Minute Book 1844-1870. MS in the library of the York Medical Society. See Greenblatt, op. cit., note 3 above, pp. 350-351.

${ }^{13}$ Ibid., p. 351.

${ }^{14}$ See Herbert Hutchinson's quotations from his father's diary entries in Herbert Hutchinson, Jonathan Hutchinson: life and letters, London, William Heinemann Medical Books, 1946, pp. 21-26. See also 'Obituary. Sir Jonathan Hutchinson, F.R.C.S., F.R.S.', Br Med J, 1913, i: 1398-1401, p. 1398.
} 


\section{Introduction}

From 1859, Hughlings Jackson lived with Hutchinson and his family at 4 Finsbury Circus, London. Through Hutchinson's influence, the younger man was appointed Physician to the Metropolitan Free Hospital and the Royal London Ophthalmic Hospital in 1859. In the same year he began his long association with the London Hospital with an appointment as lecturer in pathology.

In September 1860 Hughlings Jackson travelled to Scotland and presented himself for examination for the MD of the University of St Andrews. Licentiates of the Society of Apothecaries and Members of the Royal College of Surgeons were eligible to become candidates for the degree. On payment of the graduation fee of twenty-five guineas, the candidate could sit three days of written examination followed by an oral examination. The candidates were required to provide a written translation from the first four books of Celsus, to write prescriptions in Latin and to be able to interpret medical and scientific terms derived from Greek. In addition, they answered written questions on clinical topics. ${ }^{15}$ On 28 September 1860 a panel of the faculty examined Hughlings Jackson personally. Having satisfied the panel, the degree MD St Andrews was conferred on him on 28 September $1860 .^{16}$

Hutchinson and Hughlings Jackson were bright and ambitious young doctors, anxious to make their mark on the metropolis. First Hutchinson, then Hughlings Jackson, became medical reporters for the weekly Medical Times and Gazette. In the 14 July 1860 number, Jonathan Hutchinson began a by-lined column entitled 'Reports of hospital practice in medicine and surgery'. ${ }^{17}$ From 19 January 1861 this column carried the joint by-line of Jonathan Hutchinson and John Hughlings Jackson. ${ }^{18}$ It was rare to have a by-lined column in a weekly medical journal in that era, so the two Yorkshiremen could achieve a degree of notoriety in London medicine. As reporters, they attended lectures and rounds in the teaching hospitals of London, where their presence would have been noticed, even cultivated, by physicians anxious for a favourable public comment.

One such physician was Charles Edouard Brown-Séquard, the pioneering neurophysiologist and founding physician at the National Hospital for the Paralysed and Epileptic, Queen Square. An important influence on Hughlings Jackson, Brown-Séquard taught the primacy of physiology in medical science, an attitude that became central to Hughlings Jackson's scientific thinking. He also advised Hughlings Jackson to specialize in diseases of the nervous system. ${ }^{19}$ In 1861 Hughlings Jackson passed the examination for Membership of the Royal College of Physicians, and on 7 May 1862 he was appointed Assistant Physician at the Hospital for the Paralysed and Epileptic, proposed by Brown-Séquard. On

\footnotetext{
${ }^{15}$ See Irvine Loudon, Medical care and the general practitioner, 1750-1850, Oxford, Clarendon, 1986, pp. 214-227, and also J A Shepherd, 'Medical teaching at St. Andrews University 1413-1972', Br Med J, 1972, iii: $38-41$.

${ }^{16}$ Records of the University of St Andrews. The Critchleys write that Hughlings Jackson submitted a thesis in support of his degree, but we could find no trace of such a thesis, which was in any case not required for the degree. See Critchley and Critchley, op. cit., note 1 above, p. 33.

${ }^{17}$ Jonathan Hutchinson, 'Reports of hospital practice in medicine and surgery', Med Times Gaz, 1860, ii: 31-34.

${ }^{18}$ Jonathan Hutchinson and John Hughlings Jackson, 'Reports of hospital practice in medicine and surgery', Med Times Gaz, 1861, i: 60-63.

${ }^{19}$ See Jonathan Hutchinson, 'The late Dr. Hughlings Jackson: recollections of a lifelong friendship', Br Med J, 1911, ii: 1551-1554. For the life and work of Brown-Séquard, consult Michael J Aminoff, Brown-Séquard: a visionary of science, New York, Raven Press, 1993.
} 


\section{Introduction}

25 August 1863 Hughlings Jackson was appointed Assistant Physician to the London Hospital and in 1874 he became Physician to that hospital. ${ }^{20}$

In June 1864, Hughlings Jackson delivered a lecture at the London Hospital, later published in the London Hospital Reports, on the method of diagnostic neurology. This lecture established a system of clinical physiology that endures to this day. That summer he published a series of case analyses in the same journal that provided strong support for Paul Broca's identification of a centre for language in the left inferior frontal lobe. ${ }^{21}$ These articles established his reputation as a clinical neurologist.

On 25 July 1865, John Hughlings Jackson married the love of his life, his first cousin Elizabeth Dade Jackson, at St Giles Church, Northampton. Jonathan Hutchinson acted as best man, and described the festivities in a letter to his wife. ${ }^{22}$ By all accounts the marriage was a happy one, though Hughlings Jackson complained in a letter to his brother that he was not making as much money as he wanted. ${ }^{23}$ In 1866 Hughlings Jackson attended the victims of a cholera epidemic in the East End of London, for which he was awarded a gold watch from the governors of the London Hospital. He was proud of the watch, which he wore for the rest of his life and which now resides in the museum of the London Hospital. $^{24}$

In 1868, aged thirty-three, Hughlings Jackson was elected a Fellow of the Royal College of Physicians, a substantial achievement for someone with no university education. The next year he gave the Goulstonian lectures at the RCP, an honour usually accorded the most distinguished new Fellow. Abstracts of the lectures appeared in both the Lancet and the British Medical Journal in February and March $1869 .{ }^{25}$ In these lectures he applied the method he had announced at the London Hospital in 1864 to the study of hemiplegia. He pointed out that hemiplegia and lateralized seizures were physiologically reciprocal states. He also said that the general scientific world would look to medicine for an explanation of the function of the nervous system and the relationship of the brain and the mind. ${ }^{26}$

The London establishment sometimes lampooned the University of St Andrews because it awarded degrees to those who could pay the fee and pass the examination. To burnish its claim to scientific credibility, the St Andrews Medical Graduates Association published

\footnotetext{
${ }^{20}$ See 'Obituary. John Hughlings Jackson, M.D., F.R.C.P., F.R.S.', Br Med J, 1911, ii: 950-954, p. 950, and 'Obituary. John Hughlings Jackson, M.D. St. And., F.R.C.P. Lond., LL.D., D.Sc.,F.R.S.', Lancet, 1911, ii: 11031107.

${ }^{21}$ See J Hughlings Jackson, 'On the study of diseases of the nervous system. A lecture delivered June, 1864', Clinical Lectures and Reports by the Medical and Surgical Staff of the London Hospital, 1864, 1: 146-158, and also J Hughlings Jackson, 'Loss of speech: its association with valvular disease of the heart, and with hemiplegia on the right side.--Defects of smell._-Defects of speech in chorea.-Arterial regions in epilepsy', Clinical Lectures and Reports by the Medical and Surgical Staff of the London Hospital, 1864, 1: 388-471.

${ }^{22}$ See Herbert Hutchinson, op. cit., note 14 above, p. 229.

${ }^{23}$ Letter quoted in Critchley and Critchley, op. cit., note 1 above, p. 173.

${ }^{24}$ See Taylor, op. cit., note 1 above, p. 22, and also Critchley and Critchley, op. cit., note 1 above, pp. 41-43.

${ }^{25}$ See J Hughlings Jackson, 'Abstract of the Gulstonian [sic] lectures on certain points in the study and classification of diseases of the nervous system. Delivered at the Royal College of Physicians', Lancet, 1869, i: $307-308,344-345,379-380$, and 'Gulstonian lectures on certain points in the study and classification of diseases of the nervous system. Delivered at the Royal College of Physicians', Br Med J, 1869, i: 184, 210, and 236.

${ }^{26}$ See Lancet, ibid., p. 307.
} 


\section{Introduction}

yearly transactions between 1867 and 1873. In the 1869 Transactions, printed in 1870, Hughlings Jackson published his pivotal 'A study of convulsions', in which he described the physiology of focal epilepsy, and the localization that can result. ${ }^{27}$

The 1870s were a time of accomplishment, acclaim and personal sorrow for Hughlings Jackson. Based on clinical observations of the march of myoclonic jerks in partial epilepsy, he concluded that parts of the body were represented in discrete parts of the nervous system. His system of somatotopic organization applied to both sensory and motor systems, and was dramatically confirmed by Gustav Fritsch and Eduard Hitzig's demonstration of the electrical excitability of the motor cortex of dogs. ${ }^{28}$ Hitzig acknowledged Hughlings Jackson's achievement, which led to Hughlings Jackson's international scientific acclaim. At the same time his investigation of the workings of the nervous system led him to contemporaneous evolutionary theory. Between October 1874 and December 1876, he published a series of articles on the diagnosis of epilepsy in which he set out the principles of his theory of evolutionary neurophysiology. ${ }^{29}$

Amid this intense intellectual activity Hughlings Jackson experienced his deepest personal sorrow when, on 25 May 1876, Elizabeth Dade Jackson died unexpectedly. James Taylor, Hughlings Jackson's student, collaborator, biographer and unofficial secretary, tells us that Mrs. Jackson died of cerebral venous thrombosis complicated by Jacksonian focal seizures. ${ }^{30}$ Hughlings Jackson was shattered at the loss of his beloved companion, and remained emotionally stricken for the rest of his life.

In 1878, aged forty-three, he received an important scientific honour when he was elected a Fellow of the Royal Society. Also in 1878 he joined John Charles Bucknill, James Crichton-Browne and David Ferrier as founding editors of the journal Brain. In March 1884 he delivered the Croonian lectures at the Royal College of Physicians on the topic of evolution and dissolution of the nervous system, a seminal moment in scientific neurology. ${ }^{31}$ In these lectures he articulated his mature conception of disease of the nervous system as a process of de-evolution, or dissolution. In this conception, the nervous system is a hierarchy of sensorimotor centres whose connections are governed by evolutionary principles.

For the next fifteen years he wrote, saw patients and participated in medical life in London. Though he is said to have lived a lonely existence after the death of his wife, he was engaged enough in medical affairs to be elected president of the Harveian Society (1886), the Medical Society of London (1887) and the Ophthalmological Society of the United Kingdom (1889). In 1890 he gave the Lumleian lectures on epilepsy at the Royal

\footnotetext{
${ }^{27}$ J Hughlings Jackson, 'A study of convulsions', St Andrews Medical Graduates' Association Transactions 1869, 1870, pp. 162-204. See also Owsei Temkin, The falling sickness, 2nd ed. rev., Baltimore, Johns Hopkins University Press, 1971 , pp. 328-344.

${ }^{28}$ G Fritsch, E Hitzig, 'Über die elektrische Erregbarkeit des Grosshirn', Archiv für Anatomie, Physiologie und wissenschaftliche Medicin, 1870: 300-332.

${ }^{29}$ See J Hughlings Jackson, 'On the scientific and empirical investigations of epilepsies', Med Press Circular, 1874, 18: 325-327, 347-352, 389-392, 409-412, 475-478, 497-499, 519-521; 1875, 19: 353-355, 397-400, 419421 ; 1875, 20: 313-315, 355-358, 487-489; 1876, 21: 63-65, 129-131, 173-176, 313-316; 1876, 22: 145-147, 185-187, 475-477.

${ }^{30}$ Taylor, op. cit., note 1 above, p. 15.

${ }^{31}$ J Hughlings Jackson, 'The Croonian lectures on evolution and dissolution of the nervous system. Delivered at the Royal College of Physicians, March, 1884', Br Med J, 1884, i: 591-593, 660-663, 703-707.
} 


\section{Introduction}

College of Physicians, becoming one of the few physicians ever honoured by the Goulstonian, Croonian and Lumleian lectureships. He was a member of the Council of the Royal College of Physicians from 1885 to 1887 , and a Censor of the College from 1888 to $1889 .^{32}$ In 1885 he was elected the first President of the Neurological Society of London, by acclamation, and gave the first Hughlings Jackson Lecture of that society on 8 December 1897. ${ }^{33} \mathrm{He}$ received honorary degrees from the universities of Edinburgh and Glasgow and Bologna. He was particularly pleased by his honorary degree from the University of Bologna, in respect of the ancient medical traditions of that university. He was awarded an honorary Doctorate of Science upon the opening of the University of Leeds, in his native Yorkshire, an honour of which he was particularly proud. ${ }^{34}$

When Hughlings Jackson retired from the London Hospital in 1894, his testimonial was chaired by the now-knighted Sir James Paget, who praised his former student as an important scientist who regarded the bedside and the laboratory as equally suited for scientific study. ${ }^{35}$ His retirement from the National Hospital at the age of sixty-five, in 1900 , was postponed five years because of his continuing contributions to neurology. Becoming progressively deaf and reclusive in his old age, he spent most of his time in his house at 3 Manchester Square. He died there, of pneumonia, on 7 October 1911, aged seventy-six years six months.

\section{Hughlings Jackson's Neurological Method}

Neurology did not exist as an organized scientific discipline in 1860. Both Todd and Brown-Séquard had medical practices in the 1850s that were mainly composed of patients with neurological diseases, but neurology as a specialty had no institutional structure. The National Hospital, Queen Square, had just been founded, but its medical staff were expected to have simultaneous appointments in general hospitals in the metropolis. Much of the medical establishment held strong biases against specialists and specialty hospitals. At the same time, grand scientific syntheses had gained currency in Victorian England. In this milieu Hughlings Jackson enunciated a practical diagnostic method that formed the basis of bedside neurology for the next hundred years.

As a medical reporter, Hughlings Jackson attended Brown-Séquard's clinical lectures, and he knew Todd's published neurological work. Both Todd and Brown-Séquard analysed cases pre-mortem and at autopsy, and both assumed that the nervous system is an aggregate of anatomically contiguous but physiologically discrete components, or organs. The phrenological assumption originated in the work of Franz Josef Gall, who sought to assess a person's character by palpation of the skull. ${ }^{36}$ The explicit analysis of pre-mortem

\footnotetext{
32 'Obituary', $B r$ Med J, note 20 above, pp. 951-2.

${ }^{33}$ J Hughlings Jackson, 'The Hughlings Jackson lecture on the relations of different divisions of the central nervous system to one another and to parts of the body. Delivered before the Neurological Society, Dec. 8th, 1897', Lancet, 1898, i: 79-87.

${ }^{34}$ Taylor, op. cit., note 1 above, pp. 21-22.

35 'Opening of the winter session in the medical schools. London Hospital. Presentation of testimonial to Dr. Hughlings Jackson, F.R.S., by Sir James Paget', Br Med J, 1895, ii: 861-863.

${ }^{36}$ Owsei Temkin, 'Gall and the phrenological movement', Bull Hist Med, 1947, 21: 275-321.
} 


\section{Introduction}

neurological signs and symptoms, followed by post-mortem inspection of the nervous system, revealed the pathological nature of a number of individual neurological diseases. By determining which neurological organs are affected and which are spared, the physician could predict the location and nature of post-mortem tissue damage. Though the phrenological technique of ascertaining character by palpation of the skull had been discredited, the phrenological assumption that the nervous system is an aggregate of separate organs, each with a distinct function, was embedded in the method of clinico-pathological correlation which characterized neurology in 1860 . However, there was as yet no consensus on the definition of neurological function or on the methods to be employed to test those functions at the bedside or in the laboratory.

Hughlings Jackson was dissatisfied with conventional case analysis of patients with neurological disease. In late 1863 he produced his first attempt at a systematic neurophysiology, a privately circulated pamphlet entitled Suggestions for studying diseases of the nervous system on Professor Owen's vertebral theory. In the introduction he wrote, "In studying the Natural History of Diseases of the Nervous System, I have experienced great difficulty, not only in arranging notes of cases, but also in thinking of the disease as a lesion of a certain physiological system." ${ }^{37}$ He went on to propose a neurophysiological system, based on Richard Owen's vertebral theory, in which each vertebral segment controls a distinct distribution of visceral organs, circulation, dermatome and myotome, all under the control of the cortex. In the preface to this pamphlet, dated 5 January 1863, he said that his interest was not in the details of the system but in understanding how the nervous system worked in health and disease. He wrote, "To sum up, I care very little about the fate of the details of the scheme, and will willingly sacrifice all of them, if I can make a better arrangement.",38

In June 1864 Hughlings Jackson mounted the podium at the London Hospital to deliver a lecture entitled 'On the study of diseases of the nervous system' ${ }^{39}$ In this lecture he emphasized that the scientific physician should address the anatomy, pathology and physiology of each patient with neurological disease. He conceived of the nervous system as an aggregate of discrete organs, each with a single function. Analysing a single symptom, hemiplegia, he showed that it was possible to diagnose focal pathology in the central nervous system.

He began this lecture, which was published in the Reports of the London Hospital, with his first quotation from a non-medical source, Bacon's dictum, "It is easier to evolve truth from error than from confusion." ${ }^{40}$ He said that most physicians believed that the major impediment to understanding neurological diseases is the lack of a method for doing so. In proposing his method, he claimed that his was a natural rather than an artificial system. His procedure was aimed to be practical, and he recommended that those who did not find it useful should simply abandon it.

\footnotetext{
${ }^{37} \mathrm{~J}$ Hughlings Jackson, Suggestions for studying diseases of the nervous system on Professor Owen's vertebral theory, London, H K Lewis, 1863, on p. 1.

${ }^{38}$ Ibid., on p. iv.

${ }^{39}$ Hughlings Jackson, 'On the study of diseases of the nervous system', op. cit., note 21 above.

${ }^{40}$ Ibid., on p. 146.
} 


\section{Introduction}

Hughlings Jackson advocated an expressly biological approach to case study, adding an explicit consideration of physiology to every study. He wrote,

Just as we study, as physiologists and anatomists, the vegetative life of general tissues, the structure of organs for special functions, and the universal harmony of most diverse functions in individuals, so we ought, as workers in the field of Practical Medicine, to study every case that comes before us; as presenting

1. Disease of Tissue. (Changes in tissue)

2. Damage of Organs.

3. DisORDER OF FunCTION. ${ }^{41}$

He expanded on this method with a consideration of rheumatic heart disease, noting that rheumatic fever was systemic, featuring focal disease in multiple organs including heart, liver and lung. Showing his wit, he gave his listeners a piece of advice. He told them never to treat patients on stethoscopic evidence only, since the heart may be a poor musical instrument but a good pump. He likened treating on stethoscopic evidence alone to a drunken ship's captain who navigated his ship around a speck of dirt on his chart, mistaking it for an island. ${ }^{42}$

He then turned his technique to diseases of the nervous system. He pointed out that the physiology of diseases of the optic, facial and ulnar nerves is very different, with dramatically different symptoms, yet their pathology might be similar. ${ }^{43} \mathrm{He}$ observed that diseases of the nervous system are not necessarily diseases of nervous tissue. For example, pathology of the vascular system or of connective tissue may disorder nervous function.

Hughlings Jackson insisted that knowing the exact organ or organs of the nervous system affected is crucially important for accurate diagnosis. He illustrated this dictum with the observation that hemiplegia may be seen in cortical syphilis, middle cerebral artery embolism, striatal haemorrhage or striatal tumour. In other words, a single symptom, hemiplegia, in a single organ, the corpus striatum, may be caused by four different pathologies. ${ }^{44} \mathrm{He}$ also pointed out that hemiplegia can occur with diseases in different anatomical locations, namely the striatum, crus cerebri, pons and medulla. ${ }^{45}$ Hence, at the bedside, the physician cannot diagnose the cause of hemiplegia without considering its localization.

Hughlings Jackson's lecture elicited some note in the metropolis, being mentioned in the British Medical Journal. ${ }^{46}$ More importantly, it gave him a reliable method for studying neurological disease, a method that he was soon to employ to dramatic effect. His first foray into theoretical neurology, which consisted mainly of the exposition of a system of study, was enough to give him a measure of notoriety in the capital. His next publication, a collection of patients with rheumatic heart disease, left middle cerebral artery embolism, right hemiparesis and aphasia, would thrust him into the centre of the dominant debate of nineteenth-century neurophysiology: what, exactly, are the functions of the nervous system?

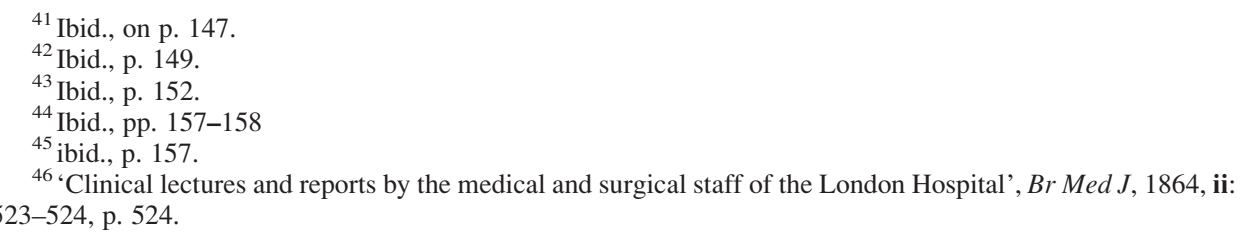




\section{Introduction}

\section{The Nature of the Epileptic Discharge}

Hughlings Jackson's first recorded neurological writing appears in the 5 February 1859 entry of the Minute Book of the York Medical Society. ${ }^{47}$ In a discussion of facial palsy, he quoted Todd in support of his views. Todd had written, "The phenomena of the epileptic fit depend upon a disturbed state of the nervous force, in certain parts of the brain-a morbidly excited polarity." 48 Influenced by his friend Michael Faraday, Todd conceived of nervous force as an electrical force. ${ }^{49}$ He taught that paralysis and spasm of muscles are reciprocal events occurring in the same location in the brain. ${ }^{50}$ Hughlings Jackson referred often to Todd's published clinical lectures, and he adopted the analytical principle that focal necrosis and focal seizures are physiologically reciprocal processes.

In an 1866 note on ocular deviation in epilepsy, Hughlings Jackson wrote that in unilateral convulsions the corpus striatum was stimulated. ${ }^{51}$ In saying this he disagreed with the prevailing view that epilepsy was due to suppression rather than excitation of function. Convinced, like Todd, that hemiplegia and unilateral convulsions were in some way reciprocal, and that disease of the same nervous tissue could lead to either epilepsy or paralysis, he had to find a more physiologically detailed version of Todd's morbidly excited polarity.

In an 1867 paper comparing regional palsy and spasm, Hughlings Jackson described epilepsy as a "sudden disorderly expenditure of force". ${ }^{52}$ Later that year he expanded this view to assert that epilepsy occurs when "the ill-nourished nerve-tissue is more unstable, over-ready, 'excitable;' there is discharge too soon; its Time is shortened."53 In his 1869 Goulstonian lectures, Hughlings Jackson again contrasted the depletion of nervous force in hemiplegia with the disorderly discharge of stored force in unilateral convulsion. $^{54}$

Shortly thereafter Hughlings Jackson published 'A study of convulsions' in the 1869 Transactions of the St Andrews Medical Graduates' Association, printed in 1870. This neurological classic begins with the observation that "a convulsion is but a symptom, and implies only that there is an occasional, an excessive, and a disorderly discharge of nerve tissue on muscles". ${ }^{55}$ In this classical description of the epileptic discharge, Hughlings Jackson assumed that the epileptic discharge originated in the cortex, notwithstanding the conventional belief that the cortex was inexcitable. He let stand the possibility that the

\footnotetext{
${ }^{47}$ Greenblatt, op. cit., note 3 above, p. 350.

${ }^{48}$ Robert Bentley Todd, Clinical lectures on paralysis, diseases of the brain, and other affections of the nervous system, Philadelphia, Lindsay and Blakiston, 1855, p. 204.

${ }^{49}$ Edward H Reynolds, 'Todd, Faraday and the electrical basis of epilepsy', Epilepsia, 2004, 45: 985-992.

${ }^{50}$ Todd, op. cit., note 48 above, pp. 204-205.

${ }^{51} \mathrm{~J}$ Hughlings Jackson, 'Note on lateral deviation of the eyes in hemiplegia and in certain epileptiform seizures', Lancet, 1866, i: 311-312, p. 311.

${ }^{52} \mathrm{~J}$ Hughlings Jackson, 'Note on the comparison and contrast of regional palsy and spasm', Lancet, 1867, i: 295-297, p. 296

${ }^{53}$ J Hughlings Jackson, 'Remarks on the disorderly movements of chorea and convulsion', Med Times Gaz, 1867, ii: 642-643, p. 643.

${ }^{54} \mathrm{~J}$ Hughlings Jackson, 'Abstract of the Gulstonian [sic] lectures on certain points in the study and classification of diseases of the nervous system. Delivered at the Royal College of Physicians', Lancet, 1869, i: 307-308.

${ }^{55} \mathrm{~J}$ Hughlings Jackson, 'A study of convulsions', op. cit., note 27 above, p. 162.
} 


\section{Introduction}

epileptic discharge depends on instability of grey matter in either the cortex or the striatum. This uncertainty was resolved by Fritsch and Hitzig's 1870 demonstration that direct electrical stimulation of different parts of the cortex in dogs evoked movement of different parts of the body. These results led Hughlings Jackson to his 1873 dictum on the nature of the epileptic discharge: "Epilepsy is the name for occasional, sudden, excessive, rapid, and local discharge of grey matter." 56

Some commentators describe Hughlings Jackson's principle of the discharge of nervous force as an electrical theory, and credit him with the first electrical theory of epilepsy. ${ }^{57}$ However, he never employed the terminology of electricity or polarity in describing epilepsy. Hutchinson tells us that chemistry was his first love, dating to his days at York Medical School. ${ }^{58} \mathrm{He}$ had a chemical orientation to brain function, and his conception of the epileptic discharge was chemical, not electrical.

In the first of his 1890 Lumleian lectures on epilepsy, Hughlings Jackson defined nervous discharge as the liberation of energy by nervous elements. ${ }^{59}$ Accepting that nervous discharges occur in health, he described the epileptic discharge as sudden, temporary and excessive in nature, a kind of explosive discharge. In his second Lumleian lecture he used a chemical analysis to describe the epileptic discharge, saying that it is a "physiological fulminate" like the gunpowder in a cannon. ${ }^{60}$ Just as gunpowder can store energy that is liberated when the gun is fired, so the energy stored in nerve cells can be explosively liberated in an epileptic discharge. He never mentions batteries, current or any other electrical ideas. Hence his theory must be considered a chemical theory rather than an electrical one.

\section{Jacksonian Epilepsy}

Somatotopic representation, the principle that different parts of the nervous system represent the sensation and movement of different body parts, is a cornerstone of diagnostic neurology. Physicians use the distribution of a patient's weakness or sensory loss to localize strokes and brain tumours. Yet this principle ran contrary to accepted physiology in 1860. At the time, experimental physiologists followed Pierre Flourens in believing that all parts of the cortex and striatum, indeed the entire brain, are equipotential. Citing avian studies, Flourens wrote that when one neurological faculty disappears they all disappear, when one sensation reoccurs they all reoccur, and when one faculty reappears, they all reappear. ${ }^{61} \mathrm{He}$ believed that all of the intellectual faculties reside in the brain, but are not further localized there. This physiology had the philosophical aim of demonstrating the

\footnotetext{
${ }^{56}$ J Hughlings Jackson, 'On the anatomical, physiological, and pathological investigations of epilepsies', West Riding Lunatic Asylum Medical Reports, 1873, 3: 315-349.

${ }^{57}$ E H Reynolds, 'Todd, Hughlings Jackson, and the electrical basis of epilepsy', Lancet, 2001, 358: 575-577.

${ }^{58}$ Jonathan Hutchinson, op. cit., note 19 above, p. 1553.

${ }^{59}$ J Hughlings Jackson, 'The Lumleian Lectures on convulsive seizures' Lancet, 1890, i: 685-688, p. 685.

${ }^{60}$ J Hughlings Jackson, 'The Lumleian Lectures on convulsive seizures', Lancet, 1890, i: 735-738, p. 736.

${ }^{61}$ Pierre Flourens, Recherches expérimentales sur les propriétés et les fonctions du système nerveux, dans les animaux vertébrés, Paris, Crevot, 1824. Translated as 'Investigations of the properties and the functions of the various parts which compose the cerebral mass', in Gerhardt von Bonin (trans.), Some papers on the cerebral cortex, Springfield, ILL, Charles C Thomas, 1960, pp. 3-21.
} 


\section{Introduction}

truth of Cartesian dualism. Flourens believed that the metaphysical soul resides in the brain, and that the soul was elemental and hence indivisible. If the soul is indivisible, then the brain must be similarly indivisible. ${ }^{62}$

Physicians approached the problem differently. In 1835, Richard Bright described a patient who was admitted to Guy's Hospital following a series of right-sided convulsions. Between attacks he had transient right hemiparesis. While hospitalized, the patient had a right-sided convulsion, during which he remained conscious. Bright wrote, "These fits were owing to some local disorganization affecting the membranes and cineritious portion of the brain on the left side, and probably influencing the deep seated parts about the posterior end of the corpus striatum." 63

At post-mortem, the patient had a subdural empyema over the left hemisphere. Bright used this case to illustrate that the left side of the striatum controlled the movement of the right side of the body. The phenomenon of lateralization, which was well known to physicians and surgeons, cast doubt on Flourens's idea of the equipotentiality of the nervous system, but was based on clinical examination rather than experimentation.

Hughlings Jackson described a common clinical occurrence which convincingly demonstrates somatotopic representation of movements in the nervous system. In some people, myoclonic movements begin in a restricted part of the body, commonly the hand, and march through one side of the body. Assuming that epileptic discharges spread from one part of the brain to the other with time, Hughlings Jackson concluded that these seizures can mean only that different parts of the nervous system control different parts of the body. The eponym "Jacksonian seizures" has been attached to focal seizures that march through different parts of the body.

The work for which Hughlings Jackson's name is eponymized was published between December 1867 and December 1868. In the 21 December 1867 edition of the Medical Times and Gazette he wrote, "Then in unilateral convulsions the 'aura' nearly always begins in the hand; sometimes, however, in the side of the face, and rarely in the leg". ${ }^{64}$ In other words, the fact that an aura may be felt first in different parts of the body means that the epileptic discharge may begin in different parts of the nervous system.

In an August 1868 commentary on the physiology and pathology of the nervous system, Hughlings Jackson wrote, "One of the most important questions we can ask an epileptic patient is, 'How does the fit begin?' ",65 He published his description and interpretation of the Jacksonian march on 19 December 1868.

I think the mode of beginning makes a great difference as to the march of the fit. When the fit begins in the face, the convulsion in involving the arm may go down the limb... When the

\footnotetext{
${ }^{62}$ Robert M Young, Mind, brain and adaptation in the nineteenth century (Oxford, Clarendon, 1970), reprinted Oxford, Oxford University Press, 1990, pp. 70-72.

${ }^{63}$ Richard Bright, 'Cases illustrative of the effects produced when the arteries and brain are diseased', Guy's Hospital Reports, 1836, 1: 9-40, on p. 36.

${ }^{64} \mathrm{~J}$ Hughlings Jackson, 'Remarks on the disorderly movements of chorea and convulsion, and on localisation', Med Times Gaz, 1867, ii: 669-670, p. 669.

${ }^{65} \mathrm{~J}$ Hughlings Jackson, 'Notes on the physiology and pathology of the nervous system', Med Times Gaz, 1868, ii: $177-179$, p. 178 .
} 


\section{Introduction}

fit begins in the leg, the convulsion marches up; when the leg is affected after the arm, the convulsion marches down the leg. ${ }^{66}$ [Emphasis in the original]

The importance of the Jacksonian march to clinical neurophysiology lies in its demonstration of somatotopic representation of the body in the nervous system. The march of ictal movements through the body recapitulates the order of anatomical representation of parts of the body in both the corpus striatum and the cortex. The Jacksonian march disproved the theory that all parts of the nervous system are functionally equipotential and validated the clinical concept that analysis of the temporal development of a focal neurological deficit is diagnostically useful. The knowledge of somatotopic representation allowed the astute neurologist to predict accurately the presence of focal pathology in the nervous system.

Jean-Martin Charcot first used the eponym "Jacksonian epilepsy". He noted that LouisFrançois Bravais had described the phenomenon in 1827, a priority which Hughlings Jackson accepted. ${ }^{67}$ Charcot wrote:

... but lately, an English scholar, Mr. Jackson of London, came back to this subject, and he discussed the issue in a way so particular that it sometimes occurred to me to call that disorder Jacksonian epilepsy and the name remained associated ever since ... Mr. Jackson's study is so important that he really deserves his name to remain connected with this discovery. ${ }^{68}$

Charcot proposed to use the eponym "Bravais-Jackson" as an alternative: "it would be fairer; it is true that it would be somewhat long", but posterity has settled on the eponym "Jacksonian epilepsy". Charcot recognized the clinical utility of the principle of somatotopic representation, a crucial diagnostic tool for the astute neurologist.

\section{Cerebral Localization}

Hughlings Jackson produced a simple, flexible scheme of cerebral localization based on evolutionary neurophysiology that is the foundation of bedside diagnosis and modern neuroscience more generally. His scheme had four components. First, the nervous system is a sensorimotor machine. Second, somatotopic representation is a weighted, ordinal process. Third, the nervous system is a hierarchy of evolutionary levels, with higher levels suppressing the function of lower ones. Fourth, the nervous system and the mind exist in parallel, neither exerting a causal effect on the other. When combined at the bedside, these principles can allow the clever examiner to predict accurately the presence of pathology in the nervous system.

\footnotetext{
${ }^{66}$ J Hughlings Jackson, 'Notes on the physiology and pathology of the nervous system', Med Times Gaz, 1868, ii: 696.

${ }^{67}$ L-F Bravais, Recherches sur les symptômes et le traitement de l'épilepsie hémiplégique, Paris, Didot le Jeune, 1827 (thèse de Paris, no. 118).

${ }^{68}$ Jean-Martin Charcot, Leçons du mardi à la Salpêtrière, Paris, Delahaye \& Lecrosnier, 1887, p.15: "Mais dans ces derniers temps, un savant anglais, M. Jackson (de Londres), est revenu sur ce sujet et il a traité la question d'une façon si particulière qu'il m'est arrivé quelquefois d'appeler cette affection l'épilepsie Jacksonienne et le nom lui en est resté.... l'étude de M. Jackson est si importante que véritablement, il méritait bien d'attacher son nom à cette découverte." And "ce serait plus juste; il est vrai que ce serait un peu long".
} 


\section{Introduction}

\section{The Sensorimotor Machine}

In 1811, Charles Bell published a privately circulated book in which he described an experiment in anaesthetized dogs. When he pricked the anterior spinal root he produced movement, but when he pricked the posterior root he produced no movement. He concluded that the anterior root was responsible for movement. ${ }^{69}$ In 1822, François Magendie divided the anterior root in dogs and produced paralysis, and divided the posterior root and produced anaesthesia. He concluded that the two roots were responsible for different functions, the anterior root being motor and the posterior root sensory. ${ }^{70}$ This became known as the Bell-Magendie hypothesis or law, which is the source of a vigorous and unresolved dispute over priority of discovery.

In 1832, the English physiologist Marshall Hall reported an experiment in which stimulation of the limbs of a decapitated turtle produced reflex movement; if the spinal cord was destroyed this reflex movement was abolished. ${ }^{71}$ Hall thus demonstrated that an intact spinal segment was necessary for reflex movement, with no need for supra-segmental influence. In a paper read to the Zoological Society, he was reported to have said that "the presence of the spinal marrow is essential as the central and cementing link between the sentient and motor nerves". ${ }^{72}$ This led Hall to promulgate a physiological principle, known as the "law of reflex action", that stated that the behaviour of the isolated spinal segment could be completely explained by the action of reflexes.

Thomas Laycock wrote on the reflex action of the nervous system, beginning in 1840. In a paper read before the Medical Section of the British Association for the Advancement of Science in 1844 , he proposed the general principle that the entire brain must be subject to the law of reflex action, since it is anatomically continuous with the spinal cord. ${ }^{73}$ This implied that no metaphysical agent was necessary to explain the function of the nervous system. Laycock was later to teach Hughlings Jackson the principles and practice of medicine at York Medical School, and heavily influenced the younger man's neurophysiological thinking. ${ }^{74}$ Hughlings Jackson quoted Laycock's paper several times in support of his contention that the nervous system is a sensorimotor machine.

The place of the metaphysical in the action of the nervous system hindered progress in neurophysiology in the mid-nineteenth century. Those who propounded ideas of sensation or movement without invoking the metaphysical properties of the soul were at risk of personal and professional criticism on theological grounds. Nevertheless, Hughlings Jackson made the claim that the action of the nervous system was not only sensorimotor, it was exclusively so.

\footnotetext{
${ }^{69}$ Charles Bell, Idea for a new anatomy of the brain; submitted for the observations of his friends, printed for private circulation, London, Strahan and Preston, 1811. Reprinted in facsimile in Paul F Cranefield (ed.), The way in and the way out, New York, Futura, 1974. The facsimile retains the pagination of the original pamphlet.

${ }^{70}$ François Magendie, 'Expériences sur les fonctions des racines des nerfs rachidiens', Journal de physiologie expérimentale et pathologique, 1822, 2: 276-279. Reprinted in facsimile in Paul F Cranefield, The way in and the way out, New York, Futura, 1974. The facsimile retains the pagination of the original article.

${ }_{71}^{71}$ Marshall Hall, Memoirs on the nervous system, London, Sherwood, Gilbert and Piper, 1837, p. vi.

${ }^{72}$ Ibid., p. vi.

${ }^{73}$ T Laycock, 'On the reflex function of the brain', Br Foreign Med Rev, 1845, 19: 298-311.

${ }^{74}$ Greenblatt, op. cit., note 3 above, pp. $348-349$.
} 


\section{Introduction}

As early as 1864, Hughlings Jackson referred obliquely to Laycock's application of the law of reflex action to the brain, though he did not elaborate on it. ${ }^{75}$ In his 1870 'Study of convulsions' he concluded that some part of the cortex had sensorimotor function, writing "Are we to believe that the hemisphere is built on a plan fundamentally different from that of the motor tract?",76 By 1874 he claimed that the nervous system is exclusively sensorimotor, writing, "The whole of the central nervous system, cerebral hemisphere, spinal cord, \&c., is made up of processes of differing degrees of complexity representing impressions and movements. There are, so far as I can judge, no other 'materials' of which the 'organ of mind' can be made up." 77 He stated this principle more succinctly in 1883 when he wrote, "The whole nervous system is a sensori-motor machine, a co-ordinating system from top to bottom." ${ }^{78}$ In 1887 he justified this opinion by reference to the law of conservation of energy, saying that immaterial agents such as volition, ideas and emotion cannot cause movement. ${ }^{79}$

This treatment of the nervous system as a machine, a soulless automaton, had both practical and personal origins. Hughlings Jackson was a committed physician, whose primary goal was to establish a workable system of diagnosis. A mechanical approach to neurophysiology proved powerfully heuristic. Moreover, Hughlings Jackson was a lifelong agnostic and strongly opposed metaphysical explanations of natural phenomena. ${ }^{80}$ There is no record of Hughlings Jackson having suffered any public sanction for promoting his ostensibly atheistic physiological doctrine; whether he was privately criticized is not known.

\section{Weighted Ordinal Representation}

Hughlings Jackson, following in the footsteps of Todd, considered focal seizures in a limb and paralysis of the same limb as reciprocal events occurring in the same part of the nervous system. This way of thinking presented him with an apparent contradiction. As he pointed out in a December 1867 note on localization, patients with mild hemiparesis have slight weakness on an entire limb rather than severe weakness of a single muscle or movement. He took this to mean that each movement is represented in every part of the motor system, a holistic type of physiology. At the same time, the march of myoclonic movements through a limb in a Jacksonian seizure implies that each part is represented in a discrete part, a localizing type of physiology. To resolve these apparently contradictory physiological conceptions, Hughlings Jackson wrote, "So the speculation is that, although each movement is everywhere represented, there are points where particular movements are specially represented." 81

\footnotetext{
${ }^{75}$ Hughlings Jackson, 'Loss of speech', op. cit., note 21 above, p. 454.

${ }^{76}$ Hughlings Jackson, op. cit., note 27 above, p. 189n.

${ }^{77}$ Hughlings Jackson, op. cit., note 29 above, 1874, 18: 347-352, on p. 348.

${ }^{78}$ J Hughlings Jackson, 'On some implications of dissolution of the nervous system', Med Press Circular, 1883, 36: 64-66, on p. 66.

${ }^{79}$ J Hughlings Jackson, 'Remarks on evolution and dissolution of the nervous system', J Mental Sci., 1887, 33: $25-48$, on p. 40.

${ }^{80}$ Jonathan Hutchinson, op. cit., note 19 above, pp. 1551-1554, p. 1553.

${ }^{81}$ Hughlings Jackson, op. cit., note 64 above, page 669.
} 


\section{Introduction}

Table 1

A graphical depiction of weighted representation. F stands for the face, A for the arm, $\mathrm{L}$ for the leg. Weighting is depicted in bold characters

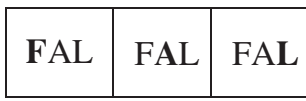

Special or weighted representation of body parts in a fundamentally holistic anatomical centre is graphically depicted in Table 1 . In this depiction, each centre contains a complete representation of the body, but each centre is weighted for a different body part. Necrosis of a single centre causes some weakness of the entire body, but much more weakness in the specific body part specially represented in that centre. An epileptic discharge beginning in one centre and moving to the contiguous ones causes a march of myoclonic movements.

Conventional neurophysiology in 1860 asserted that the will or the metaphysical soul controls or regulates the function of the cortex, which in turn controls the rest of the nervous system. Hughlings Jackson accepted the idea of control of function but rejected an immaterial agent of control. Rather, he conceived of a hierarchy of sensorimotor centres in which anatomically higher centres control the function of lower centres. He saw the nervous system as a three-level hierarchy which he called lower, middle and highest centres. He further asserted that each element of the middle and highest centres contains a complete representation of the next lower level.

Table 2

A graphical depiction of weighted ordinal representation. F stands for the face, A for the arm, $\mathrm{L}$ for the leg. Middle level weighting is depicted in bold characters, highest level weighting is depicted by underlined characters

\begin{tabular}{|l|l|l|l|}
\hline \multirow{4}{*}{ Highest level } & FAL & FAL & FAL \\
Middle level & FAL & FAL & FAL \\
Lowest level & FAL & FAL & FAL \\
\hline Face & Arm & Leg \\
\hline
\end{tabular}

The three-level hierarchy is graphically depicted in Table 2. In this depiction, each centre in the middle and highest levels contains a complete representation of the next lower level, but each is also weighted for a particular body part.

This scheme explains the partial weakness of an entire limb in mild hemiparesis because each centre in the middle level and highest levels contains a full representation of the body, and loss of it causes weakness throughout the body. It also explains the march of movements in a Jacksonian seizure because each centre is weighted for a different body part. This type of nested representation is ordinal, in the sense that each level is ordered by inclusion. 


\section{Introduction}

\section{Evolutionary Neurophysiology}

The scientific and cultural firestorm that followed the publication of On the origin of species extended to medicine, leading Hughlings Jackson to apply explicitly evolutionary principles to neurophysiology. In his series of articles on the investigation of epilepsy, printed in the weekly Medical Press and Circular from 1874 to 1876, Hughlings Jackson adapted Herbert Spencer's evolutionary theory to neurological disease. In this series of articles he addressed the relationship between the centres in his hierarchy, concluding that this relationship conformed to evolutionary principles. Following Spencer, he concluded that the highest nervous centres evolved out of the lower. He wrote, "The very highest of all nervous centres are but complex rearrangements of lower centres, and these of still lower centres unto the lowest, which last directly represent impression and movements." 82 In 1882 he stated, "The higher the centre the more numerous, different, and more complex, and more special movements it represents." 83

Hughlings Jackson expressed the pathophysiology of the nervous system as the reverse of evolution, or dissolution. As early as 1873 he asserted that patients with dissolution of the nervous system should exhibit symptoms which are less evolved than usual. He interpreted this to mean that a patient's symptoms should be less complex, less specialized and less voluntary than normal subjects. ${ }^{84}$ Patients with diseases of the highest centres develop two types of symptoms, negative symptoms due to the loss of higher centres and positive symptoms due to the emergence of lower centres. Positive symptoms are simpler and less differentiated than the negative symptoms which they replace.

In 1875, Hughlings Jackson used post-ictal mental disorders to illustrate the relationship of the cortex to the basal ganglia. ${ }^{85}$ If the sudden discharge of nervous energy produces an epileptic seizure, then seizures which begin with discharge of higher centres start with loss of consciousness, but those which begin with discharge of lower centres spare consciousness. According to Hughlings Jackson, post-ictal mental symptoms, like post-ictal physical ones, have the two components predicted by evolutionary theory: the negative symptom of post-ictal confusion, from the temporary paralysis of higher centres, and the positive symptoms of post-ictal mania or agitation, from the emergence of the function of the previously inhibited lower centres.

Over the succeeding years Hughlings Jackson elaborated these themes. In 1882 he identified the specific anatomic structures corresponding to each motor level. The lowest level, representing parts of the body most directly, consists of the anterior spinal horns and homologous cranial motor nerve nuclei. The middle level, which re-represents the body, is composed of the motor cortex and the basal ganglia. The highest level, which re-rerepresents the body, consists of the premotor frontal cortex. ${ }^{86}$

\footnotetext{
${ }^{82}$ Hughlings Jackson, op. cit., note 29 above, 1874, 18: 347-352, on p. 348.

${ }^{83} \mathrm{~J}$ Hughlings Jackson, 'On some implications of dissolution of the nervous system', Med Press Circular, 1882, 34: 411-414, on p. 412.

${ }^{84} \mathrm{~J}$ Hughlings Jackson, 'On the anatomical and physiological localisation of movements in the brain', Lancet, 1873 , i: $84-85$.

${ }^{85}$ J Hughlings Jackson, 'On temporary mental disorders after epileptic paroxysms', West Riding Lunatic Asylum Medical Reports, 1875, 5: 105-129.

${ }^{86}$ Hughlings Jackson, op. cit., note 83 above.
} 


\section{Introduction}

In his March 1884 Croonian lectures, Hughlings Jackson presented his mature theory of cerebral localization as practical evolutionary physiology. Delivered at the Royal College of Physicians in London, these lectures were published in the British Medical Journal, the Lancet, and the Medical Times and Gazette. In them, Hughlings Jackson presented to the world a detailed explication of his evolutionary neurophysiology. ${ }^{87}$ In his first lecture he reiterated the dual nature of neurological symptoms. He claimed that, "the symptomatology of nervous diseases is a double condition; there is a negative and a positive element in every case", 88

He went on to point out that disease or dissolution can be uniformly distributed through the nervous system or can be confined to a small local area. Focal dissolution can involve one neurological system or several, and could extend through one or two evolutionary levels. He wrote,

We make two broad divisions of cases of dissolution, Uniform and Local. In Uniform Dissolution the whole of the nervous system is under the same conditions or evil influence; the evolution of the whole nervous system is comparatively evenly reversed ... The next division is Local Dissolution. Obviously, disease of a part of the nervous system could not be a reversal of the evolution of the whole; all that we can expect is a local reversal of evolution ... ${ }^{89}$

In his second lecture Hughlings Jackson introduced the idea of tonic inhibition, set in evolutionary terms. He claimed that higher levels suppress the function of lower levels:

The higher nervous arrangements evolved out of the lower keep down those lower, just as a government evolved out of a nation controls as well as directs that nation. If this be the process of evolution, then the reverse process of dissolution is not only a "taking off" of the higher, but is at the very same time a "letting go" of the lower. ${ }^{90}$

\section{The Doctrine of Concomitance}

In his third Croonian lecture Hughlings Jackson first enunciated his doctrine of concomitance. He asserted that the nervous system is an explicitly sensorimotor machine arranged as an evolutionary hierarchy. He recognized human consciousness as the highest level of mental evolution, the analogue of the highest level of evolution of the nervous system. This generated an urgent question: how, if at all, are these two highest expressions of evolution related to one another?

Hughlings Jackson knew at least three theoretical solutions to the mind-body problem. In the first, the "mind acts through the nervous system ... here an immaterial agency is supposed to produce physical effects". 91 Though he does not mention Descartes, this

\footnotetext{
${ }^{87}$ Hughlings Jackson, op. cit., note 31 above. See also J Hughlings Jackson, 'Croonian lectures on the evolution and dissolution of the nervous system. Delivered at the Royal College of Physicians', Lancet, 1884, i: 555-558, 649-652, 739-744, and J Hughlings Jackson, 'Croonian lectures on evolution and dissolution of the nervous system. Delivered at the Royal College of Physicians', Med Times Gaz, 1884, i: 411-413, 445-448, 649-652. The published lectures were, in part, transcribed verbatim by an unknown note-taker, and in part paraphrased.

${ }^{88}$ Hughlings Jackson, op. cit., note 31 above, p. 591.

${ }^{89}$ Ibid., p. 591.

${ }^{90}$ Ibid., p. 662.

${ }^{91}$ Hughlings Jackson, op. cit., note 79 above, p. 37.
} 


\section{Introduction}

version can be recognized as Cartesian dualism. In the second solution, "activities of the highest centres and mental states are one and the same thing", 92 a statement of the mindbrain identity theory. The third version says that brain states and mental states are intrinsically different, occur in parallel and have no causal interaction between them. ${ }^{93}$ This brain-mind theory, a form of psychophysical parallelism, Hughlings Jackson called the doctrine of concomitance.

Hughlings Jackson recognized that any solution to the mind-body problem was not a medical but a philosophical theory, which he specifically termed metaphysical. Under most circumstances he strongly rejected metaphysical explanations for medical observations, even denying that comatose persons were unconscious, because consciousness is a metaphysical concept. None the less, he embraced the doctrine of concomitance because it allowed a practical analysis of neurological disease which conformed to his clinical observation. $^{94}$

The doctrine of concomitance was not Hughlings Jackson's invention. He claimed that a number of other Victorian scientists and philosophers held similar views, including Thomas Henry Huxley, John Stuart Mill, Alexander Bain, Herbert Spencer and Thomas Laycock. ${ }^{95}$ The basic idea can be traced to the work of the German philosopher Leibniz, which was known to both Laycock and Hughlings Jackson. ${ }^{96}$ The latter admitted that his doctrine of concomitance could be construed as a form of Leibniz's "two clock theory", in which one clock is timed to strike when the other showed the hour. ${ }^{97}$ This is taken as an analogy of the non-causal parallelism of brain and mind.

\section{The Rejection of the Unconscious}

Hughlings Jackson's assertion that the mind exists in parallel to the nervous system, and that the nervous system has an evolutionary structure, led him to subject the mind to a similar evolutionary analysis. Consciousness, as the highest level of mental evolution, could be seen as the most complex, most specialized, most integrated, and most interconnected mental function, analogous to the highest level of the nervous system. ${ }^{98}$ As a practical physician, he sought to find evolutionary levels of the mind, with the aim to treat mental disease.

Hughlings Jackson reasoned that the structure of the mind should strictly follow the structure of the nervous system. He thought that if the nervous system is composed of evolutionary levels connected by a process of representation, and if the mind and the brain are related by the doctrine of concomitance, then the mind can also be understood as having evolutionary levels connected by representation. Furthermore, just as states of the highest

${ }^{92}$ Ibid.

${ }^{93}$ Ibid.

${ }^{94}$ Ibid., pp. 38-39.

${ }^{95}$ Ibid., p. 38.

${ }^{96}$ Ibid. See also Thomas Laycock, Mind and brain: or, the correlations of consciousness and organization, with their applications to philosophy, zoology, physiology, mental pathology, and the practice of medicine, Edinburgh, Sutherland and Knox, 1860, p. 183. Laycock comments, "In Germany, the doctrine of Leibniz was almost universally adopted."

${ }^{97}$ Hughlings Jackson, op. cit., note 79 above, p. 38.

${ }^{98}$ Ibid., p. 39. 


\section{Introduction}

level of nervous evolution have concomitant mental states, so states of the middle and lower levels of nervous evolution should have concomitant mental levels. It stands to reason that any mental state lower than consciousness is unconscious. Hence, if the combination of nervous system evolution and concomitance is correct, then unconscious mental states must exist as the logical concomitants of lower levels of evolution of the nervous system. This brought Hughlings Jackson to consider the following question: how far down the evolutionary hierarchy of the nervous system are there concomitant mental states? In Hughlings Jackson's words, "What is the range of concomitance?" 99

Even before he enunciated his doctrine of concomitance, he accepted the existence of unconscious mental states and actions as the source of spoken words. In an 1878 article on aphasia, published in the first volume of the journal Brain, he wrote that "perception is the termination of a stage beginning by the unconscious or subconscious revival of images". 100 Echoing the ideas of G H Lewes, he noted the possibility that all nervous centres have a psychological side, presumably including the spinal cord. ${ }^{101}$

Four years later he expressed more serious reservations about the existence of unconscious mental states. In an 1881 series of articles on post-epileptic states he claimed that all mental states have concomitant physical states, but asked the question whether the converse is true. ${ }^{102}$ Specifically, he asked whether states of the lower nervous centres have concomitant mental states. He wrote, "Is there any sort of subconsciousness or sensibility or any sort of psychical state, however rudimentary, attending functioning of any lower nervous arrangements? .. I I express no opinion on this most difficult question." ${ }^{103}$ In his third Croonian lecture he again attributed to Lewes the thesis that some degree of consciousness attends activity of all levels of nervous activity. However, by this time he seemed inclined to deny that unconscious states of mind existed, though he again was unsure. He wrote, 'Some, indeed, speak of 'unconscious states of mind,' as if, below consciousness, there were some faint mental states. I am not sure that I state this view with verbal correctness, as I do not understand it.",104

In his April 1887 commentary on the evolution and dissolution of the nervous system he returned to a discussion of the range of concomitance. ${ }^{105}$ He stated that he thought that the entire body is the organ of mind, but asks that, for the sake of argument, the highest level of the nervous system be considered the organ of mind. He then asserted that consciousness and mind are synonymous terms. Following this, he explicitly rejected unconscious mental states:

Unconscious states of mind are sometimes spoken of, which seems to me to involve a contradiction. That there may be activities of lower nervous arrangements of the highest centres, which have no attendant psychical states, and which yet lead to next activities of the very highest nervous arrangements of those centres whose activities have attendant psychical

\footnotetext{
${ }^{99}$ Ibid., p. 39.

${ }^{100}$ J Hughlings Jackson, 'On affections of speech from disease of the brain', Brain, 1878, 1: 304-330, p. 325.

${ }^{101}$ Ibid., footnote on p. 323.

${ }^{102} \mathrm{~J}$ Hughlings Jackson, 'Remarks on dissolution of the nervous system, as exemplified by certain postepileptic conditions', Med Press Circular, 1881, 31: 329-332, 399-400, 1881, 32: 68-70, 380-382, 399-401,

${ }^{103}$ Ibid., 32: 69 .

${ }^{104}$ Hughlings Jackson, op. cit., note 31 above, p. 706.

${ }^{105}$ Hughlings Jackson, op. cit., note 79 above.
} $421-422$. 


\section{Introduction}

states, I can easily understand. But those prior activities are states of the nervous system, not any sort of states of mind. ${ }^{106}$

This article exposes Hughlings Jackson's dilemma. He had concluded that if the highest level of brain evolution has the concomitant mental state of human consciousness, then lower levels of brain evolution also must have concomitant, unconscious, mental states. But no such states are apparent clinically; an unconscious patient is simply unresponsive. Hughlings Jackson resolved this by rejecting the entire idea of the unconscious, stating that any state of mind is by definition conscious, and indeed cannot be otherwise. Unconscious mental states are, for Hughlings Jackson, a contradiction.

Hughlings Jackson's change of mind was the result of his evolutionary thinking. If the nervous system is composed of discrete evolutionary levels, and if higher levels control or suppress the action of lower levels, then disease which affects a given level will have two symptoms. One symptom, a negative one, is the result of loss of function of the higher, controlling level; the other symptom, a positive one, is the result of the appearance of function of the lower, previously inhibited level. Hughlings Jackson's application of this method to the study of epilepsy and aphasia had striking practical value.

As an example of this method, Hughlings Jackson considered the symptoms of aphasia. He observed that aphasic patients cannot speak grammatically, cannot write and have difficulty with pantomime. He identified these as the negative element of the disease, reflecting dissolution of the highest level of the nervous system. He also observed that these patients utter stereotypic words or phrases, which at times have a clear semantic content and at other times are apparently meaningless. These recurrent utterances he identified as the positive element of the illness, which is an expression of the release or dis-inhibition of the middle evolutionary level. ${ }^{107}$

Hughlings Jackson used the same reasoning to consider the mind. If consciousness is the highest level of mental evolution, and a patient loses consciousness as the negative element of the illness, then what remains must be the positive expression of lower, unconscious mental function. However, as an experienced and astute physician, he had examined many unconscious patients, and he knew that an unconscious individual did not manifest any easily identifiable mental function at all. Instead, the patient lies in bed, mute and uncomprehending. Such a person offers little evidence of unconscious speech or action, despite showing unequivocal evidence of positive signs of function of lower levels of the nervous system. $^{108}$

He also used the example of complex post-epileptic behaviour. He had observed that after epileptic fits some patients act elaborately, in ways which seem to involve complex mental activities. Later the patient has no memory of the event. He commented, "To say that the patient had unconscious or latent states of mind does not, I think, help us." ${ }^{109}$ In other words, during a time of temporary dissolution of the nervous system, he could observe no states of mind which could be construed as unequivocally unconscious.

\footnotetext{
${ }^{106}$ Ibid., pp. 39-40.

${ }^{107}$ Hughlings Jackson, op. cit., note 100 above.

${ }^{108}$ Hughlings Jackson, op. cit., note 31 above, p. 661.

${ }^{109}$ Hughlings Jackson, op. cit., note 79 above, p. 40.
} 


\section{Introduction}

Hughlings Jackson had a practical motivation for his rejection of the unconscious. His commitment to the idea of the nervous system as a sensorimotor machine made him reject explanations of nervous system disease in psychological or philosophical terms. As a physician, he aimed to develop a system that was useful at the bedside. This produced an extreme empiricism, so that he could not accept a theory that had no visible examples in everyday neurological practice. He specifically disavowed any philosophical interest in the mind-body relationship, saying, "I am not competent to discuss the metaphysical question of the nature of the relationship of mind to nervous activities." ${ }^{110}$ Elsewhere he stated, "As an Evolutionist I am not concerned with this question, and for medical purposes I do not care about it." 111 This ultimately led to his perplexity in the case of the range of concomitance.

Hughlings Jackson changed his mind because his strict personal standards required him to reject ideas which he could not validate, even if those ideas were his own. His colleagues and friends tell us of his intellectual honesty and personal rectitude. Hutchinson said that his "love of truthfulness was very strong". ${ }^{112}$ His colleague Charles Mercier remarked on his "high standards of rectitude". ${ }^{113}$ His student and collaborator James Risien Russell wrote, "No sordid motives influenced him in his life-work, which goes down to posterity as a monument of his greatness." 114 In a man of such intellectual integrity, it does not seem out of character that he should reject his own previously held opinion if he could no longer defend it.

In summary, Hughlings Jackson initially assumed that the structure of the mind is exactly analogous to the structure of the nervous system. Applying this analogy to neurological diseases, pathological states involving the loss of consciousness should be accompanied by positive mental symptoms caused by dis-inhibition of sub-conscious mental states. Hughlings Jackson recognized that there was a problem with his analysis when he did not observe the predicted mental states in unconscious patients. He could explain this by altering either his assumption about the structure of the mind or the doctrine of concomitance that predicted that structure. He followed the latter course, rejecting the general interpretation of concomitance and restricting the range of concomitance to the highest level of evolution of the nervous system. In doing so he rejected the existence of unconscious mental states.

\section{Aphasia}

In 1864, Hughlings Jackson published a series of cases aimed at illustrating his method of case analysis in pathological, anatomical and physiological terms. ${ }^{115}$ In this series, published in the London Hospital Reports, he collected 34 cases of patients with cardiac valvular

\footnotetext{
${ }^{110}$ Ibid., p. 37.

${ }^{111}$ Hughlings Jackson, 'On post-epileptic states: a contribution to the comparative study of insanities', J Mental Sci, 1888, 34: 349-365, on p. 350.

${ }^{112}$ Jonathan Hutchinson, op. cit., note 19 above, p. 1553.

113 'The late Dr. Hughlings Jackson. Recollections by Dr. Mercier', Br MedJ, 1912, i: 85-86, on p. 85. Obituary, Br Med J, op. cit., note 20 above, p. 953.

${ }^{114}$ Obituary, $\operatorname{Br}$ Med $J$, op. cit., note 20 above, p. 953.

${ }^{115}$ Hughlings Jackson, 'Loss of speech', op. cit., note 21 above.
} 


\section{Introduction}

disease, hemiplegia and loss of speech. Asserting that the cause of the neurological symptoms was embolism to the middle cerebral artery, he found that 31 patients had right hemiplegia. He claimed no novelty in these observations, crediting Paul Broca with developing the principle that disease of the third left frontal convolution led to loss of articulate language. He wrote, "M. Broca believes that disease of the left side of the brain only, produces loss of Language; and moreover, he locates the faculty of Articulate Language in a very limited part of that hemisphere. My observations tend to support the first hypothesis, and, in a general way, the second." ${ }^{116} \mathrm{He}$ also credited Brown-Séquard, a friend of Broca, with teaching him to distinguish between speech, articulation and voice.

Hughlings Jackson's chief contribution to the aphasia debate was his rejection of the principle that brain functions are psycho-physiological faculties. Broca had distinguished between a general faculty of language, a mental faculty manifested in all forms of expression including sign language and writing, and a faculty of articulate language, or speaking. Hughlings Jackson, in his 1864 series, found that all patients had defects of all modalities of expression, yet had disease in the distribution of the left middle cerebral artery. He also observed that, in order to distinguish between troubles of articulation and speech, it is useful to have the patient attempt to communicate by writing.

By 1866 Hughlings Jackson had concluded that, although Broca's aphasia resulted from disease of the left frontal lobe, the faculty of articulate language, as such, did not exist. He wrote, "I think, then, that the so-called 'faculty' of language has no existence, and that disease near the corpus striatum produces defect of expression (by words, writing, signs, etc.) to a great extent, because this is the way out from the hemisphere to the organs which the will can set in motion." 117 That is, aphasic patients have normal mental function, but cannot translate inner language to speech. He distinguished between intellectual and emotional speech; Broca's aphasia affects intellectual speech, but the remaining utterances of aphasics represent the residual emotional speech. In an 1866 letter to the editor of the Medical Times and Gazette, he also made the interesting observation of the coexistence of aphasia and left hemiparesis in a patient who lamented his paralysis because he was left handed. ${ }^{118}$

Both Broca and Hughlings Jackson believed that the association of aphasia and hemiplegia was due to the combined disease of the cortex and the corpus striatum. Orthodox neurophysiological opinion held that the cortex served mental operations while the striatum served motor function, and that the cortex was inexcitable. In changing these beliefs, Hughlings Jackson made his most durable contribution, the fundamental principle of diagnostic neurology: the concept of evolutionary neurophysiology applied to the bedside.

\section{Recovery}

Hughlings Jackson's analysis of evolution and dissolution of the nervous system had to explain a common event in clinical practice, namely that people often recover substantially

${ }^{116}$ Ibid, on p. 388 .

${ }^{117} \mathrm{~J}$ Hughlings Jackson, 'Notes on the physiology and pathology of language. Remarks on those cases of disease of the nervous system in which defect of expression is the most striking symptom', Med Times Gaz, 1866, i: $659-662$, p. 660 .

${ }^{118} \mathrm{~J}$ Hughlings Jackson, 'Hemiplegia of the left side, with defect of speech', Med Times Gaz, 1866, ii: 210. 


\section{Introduction}

after focal necrosis of the nervous system, for example after a stroke. His system of weighted ordinal representation, taken as a static system, could not explain this progressive recovery because, if the representation of the affected movement is fixed, then the degree to which undamaged areas can compensate should also be fixed. However, this conflicted with the clinical observation that, as time progressed after a focal brain injury, the affected movement steadily improved. Because of this, Hughlings Jackson concluded that the weighting of representation had to be a dynamic process, which he called the Principle of Compensation.

In Jacksonian compensation, if one element is damaged, other elements with less weighted representation continue to act, in proportion to their initial weighting. This includes elements of the same evolutionary level, and also elements of different levels. If more elements are damaged, fewer undamaged areas remain, and the degree of loss of function is greater. In addition, damage to higher levels produces less severe symptoms than damage to lower levels, because higher levels contain more complex and interconnected representations of the damaged area and therefore compensate more fully in the event of brain injury.

The concept of weighted representation meant that this system could be a dynamic one. Re-weighting of representation in undamaged areas of the nervous system implies that, in progressive recovery, some areas will become more active and others less active than in the normal, undamaged brain. This aspect caused Hughlings Jackson to write that the loss of a particular movement is "largely compensated in time by greater activity" of the remaining areas. ${ }^{119}$ As time passes, there appears "to be decided paralysis of X only, but slowly the other terms come to serve for moving the whole region more efficiently and what is called the paralysis of $\mathrm{X}$ diminishes". 120

While Hughlings Jackson's examples of compensation were most often taken from the motor system, he intended that it apply to the entire nervous system, including the somatosensory and special sensory systems. In an 1876 analysis of post-ictal paralysis, he raised doubts that total deafness or total blindness could result from cortical injury, because undamaged sensory areas could partially compensate for the damaged areas. ${ }^{121}$ However, in a footnote, he raised the possibility that symmetrical damage to the appropriate cortical areas might completely obliterate vision or hearing. Nevertheless, he wrote that "the Principle of Compensation, I suppose, hold[s] for all nervous centres". ${ }^{122}$

Hughlings Jackson reasoned that, if compensation applied to circumstances in which parts of the nervous system were destroyed, it should also apply to clinical states in which parts of the nervous system were stimulated, namely epilepsy. In "inverted compensation", the disordered movements in a tonic-clonic seizure are the result of simultaneous discharge of many elements with different representation, including heavily weighted and other, more lightly weighted, areas. Movements elicited in this way, the result of

\footnotetext{
${ }^{119}$ Hughlings Jackson, ‘On some implications of dissolution of the nervous system', Med Press Circular, 1882, 34: 433-434, on p. 433.

${ }^{120}$ Ibid., p. 434.

${ }^{121}$ J Hughlings Jackson, 'On epilepsies and on the after-effects of epileptic discharges (Todd and Robertson's hypothesis)', West Riding Lunatic Asylum Medical Reports, 1876, 6: 266-309.

${ }^{122}$ Ibid., p. 290.
} 


\section{Introduction}

activity of all motor areas acting simultaneously, were not normal but rather distinctly abnormal. $^{123}$

\section{Ophthalmology in its Relation to General Medicine}

Hughlings Jackson's first hospital appointment was to the Royal London Ophthalmic Hospital, commonly called the Moorfields Eye Hospital. He recognized the importance of ophthalmology in the study of neurological disease, and carefully examined and reported eye findings in his cases. He integrated ophthalmology into scientific neurology, in the process measurably improving the sensitivity of bedside diagnosis. In recognition of his contributions to ophthalmology, he was selected to give the 1877 Annual Oration to the Medical Society of London, and the 1885 Bowman Lecture and 1889 Presidential Address to the Ophthalmological Society of the United Kingdom. In each lecture he described important ophthalmological findings in neurological disease. ${ }^{124}$

His classic 1877 lecture, entitled 'Ophthalmology in its relation to general medicine', contains a wealth of neurological insight. ${ }^{125} \mathrm{He}$ stressed the importance of routine ophthalmoscopic examination, and said that vision must be corrected refractively before it could be analysed neurologically. As an example of systematic ophthalmoscopy, he pointed to the fact that patients with brain tumours could have bilateral papilledema, which he called optic neuritis, despite normal vision. This fact obliged the practical physician to examine every patient's eyes ophthalmoscopically. At the same time, the examiner can evaluate the retinal vessels as an indirect indication of the state of the cerebral circulation. This technique allowed Hughlings Jackson to perform one of his two published experiments. Applying ice to the back of the head while simultaneously examining the retinal vessels, he concluded that this manoeuvre did not alter the cerebral blood flow. ${ }^{126}$

In his 1877 lecture he noted that patients with ocular signs of syphilis and focal seizures most likely have neurosyphilis, that diphtheria causes a unique ciliary paralysis, and that patients with ophthalmoplegia often complain of vertigo. He asserted that there are centres for conjoint movements of the eyes, which can be damaged unilaterally with diseases in the frontal cortex or the brainstem. Quoting Charcot, he noted that hemispheric disease could produce hemianopsia. Ophthalmoscopic examination could reveal ocular emboli and the signs of Bright's disease. ${ }^{127}$

\footnotetext{
${ }^{123}$ Hughlings Jackson, op. cit., note 119 above.

${ }^{124} \mathrm{~J}$ Hughlings Jackson, 'An address on ophthalmology in its relation to general medicine', $\mathrm{Br}$ Med J, 1877, i: 575-577, 605-606, 672-674, 703-705, 804-805; J Hughlings Jackson, 'Ophthalmology and diseases of the nervous system, being the Bowman lecture, delivered Friday, November 13th, 1885, Trans Ophthalmol Soc U.K., 1886, 6: 1-22; J Hughlings Jackson, 'Presidential address, delivered at the first meeting of the session, October 17th, 1889', Trans Ophthalmol Soc U.K., 1890, 10: xliv-lix. See also Burton Chance, 'Short studies on the history of ophthalmology. III. Hughlings Jackson, the neurologic ophthalmologist, with a summary of his works', Arch Ophthalmol, 1937, 17: 241-289.

${ }^{125} \mathrm{Br}$ Med J, 1877, i: 575-577, 605-606, 672-674, 703-705, 804-805.

${ }^{126} \mathrm{~J}$ Hughlings Jackson, 'An experimental inquiry into the effect of the application of ice to the back of the neck on the retinal circulation', Med Times Gaz, 1863, ii: 90-91.

${ }^{127}$ Hughlings Jackson, $\mathrm{Br}$ Med $\mathrm{J}$, op. cit., note 125 above, pp. 703-704.
} 


\section{Introduction}

\section{Hughlings Jackson's Philosophy}

Modern writers see a philosophical motivation in Hughlings Jackson's neurophysiology, which they attribute to either a youthful intent to abandon medicine in pursuit of a career in academic philosophy, or a mature interest in formal philosophy. However, an examination of his early crisis of intention in the context of his background and his personality reveal it to be a literary ambition of a sort common in Victorian Britain, rather than a desire to be an academic philosopher. Later, when discussing his neurological work, Hughlings Jackson expressly and repeatedly disclaimed philosophical motivation. Instead, he claimed that the needs of practical medicine motivated his theoretical work.

The story of Hughlings Jackson's youthful crisis of intention is found only in Hutchinson's 1911 British Medical Journal obituary, written fifty years after the events described. ${ }^{128}$ Hutchinson's entire description of this episode, published a week after his friend's death, is as follows:

When Dr. Jackson and myself first made acquaintance he had been some two or three years in the profession, and, in the belief that it did not afford attractive scope for mental powers of which he was not unconscious, he was on the point of abandoning it, intending to engage in a literary life. From this I was successful in dissuading him, and for many years I plumed myself upon this as the most successful achievement of my long life. Of late, however, I have had my misgivings, and have doubted whether — great as had been the gain to medicine-it might not have been a yet greater gain to the world at large if Hughlings Jackson had been left to devote his mind to philosophy. There are others who are better skilled than myself to give an opinion on this head, but at some future time I may hope to be able to produce some details in illustration of his character which may go far to justify my misgivings. ${ }^{129}$

Eight weeks later Hutchinson wrote a longer memoir, but did not expand on Hughlings Jackson's literary or philosophical ambitions. ${ }^{130}$

The young Hughlings Jackson was undoubtedly ambitious, but the nature and direction of his ambition must be viewed in context. Lacking university education, he had no chance of an academic career, philosophical or otherwise. He came from yeoman stock, and his family seem to have been religious dissenters. Therefore, he had very little chance of gaining admission to what might be called a philosophy school or graduate programme, much less being appointed to an academic position in philosophy.

Practical considerations of money and family give a more plausible explanation of this episode. Hughlings Jackson's father Samuel became impoverished late in his life, and, in the same period, his three brothers emigrated and his sister died. He might have received some compensation as a houseman, but he probably received little support from his family. With his father in straitened circumstances and in failing health, it appears quite likely that he lived a threadbare existence. In the summer of 1859 he moved to London permanently, short of money but burning with ambition and well aware of his own intellectual powers. It was at this time that he had his crisis of intention.

At the age of twenty-four, with little money, he no doubt sought to use his intellect to make a living, and he probably considered medicine only one of several options. For

\footnotetext{
128 'Obituary', $B r$ Med J, op. cit., note 20 above.

${ }^{129}$ Ibid., p. 952.

${ }^{130}$ Hutchinson, op. cit., note 19 above.
} 


\section{Introduction}

example, he must have known something of the law, since one of his brothers was a lawyer. He also read voraciously, most notably Carlyle and Dickens. In thinking how a self-aware, medically sophisticated intellectual might support himself in 1859 London, Hughlings Jackson must have considered some type of writing for money. Hutchinson would have interpreted this as a "literary life". There is no evidence that he considered writing fiction, though there is no a priori reason to reject this possibility. More likely, though, he was thinking of non-fiction or journalism. It seems far-fetched to imagine the ambitious young Hughlings Jackson taking rooms in a university to study philosophy, even had he the background to do so.

Furthermore, grand scientific syntheses were becoming a social and publishing phenomenon in mid-Victorian Britain. The success of Robert Chambers's Vestiges of the natural history of creation, first published in 1844, emboldened Darwin and Spencer to publish their own synthetic works. These volumes had wide appeal among the increasingly literate and prosperous public, as reflected in their sales. None of these writers were academic scientists, though they might be called literary scientists or even literary philosophers. An ambition to write treatises of synthetic science, rather than to pursue a career in academic philosophy, seems a better explanation of Hughlings Jackson's goal of a "literary life".

In later life Hughlings Jackson was a prolific writer. Assessing any writer's motivation is a difficult task, a task made doubly difficult in Hughlings Jackson's case because he had his executor burn his personal papers after his death. Little autograph material remains other than his published works, but he did leave a number of published comments about his creative motivation. These show him to be a practical physician whose primary motivation was medical science rather than theory or philosophy. Moreover, he published exclusively in medical journals, lectured mainly to medical audiences and spent his days practising medicine. Therefore he could expect to have his work seen and criticized by his fellow physicians, but not necessarily by academic scientists or academic philosophers.

Hughlings Jackson specifically rejected metaphysics and materialism, two areas of Victorian philosophical inquiry. In a preface to his 1875 pamphlet on cerebral localization, he said that it is possible to practise medicine with any type of metaphysical beliefs, or none at all: "That along with excitations or discharges of nervous arrangements in the cerebrum, mental states occur, I, of course, admit; but how this is I do not inquire; indeed, so far as clinical medicine is concerned, I do not care."131 The next year, in a paper on Todd's paralysis, he wrote that the aim of his mechanical view of the nervous system was to combat metaphysical neurophysiology. He discounted the philosophical idea that there exists a centre of the nervous system that acts as a metaphysical interpreter, standing outside sensory and motor function. ${ }^{132}$

In an address to the Section of Pathology at the August 1882 meeting of the British Medical Association in Worcester, Hughlings Jackson criticized metaphysical

\footnotetext{
${ }^{131} \mathrm{~J}$ Hughlings Jackson, Clinical and physiological researches on the nervous system. No. 1. On the localisation of movements in the brain, London, J and A Churchill, 1875, held in the Rockefeller Library, Institute of Neurology, University College London. This item, including the preface, also appears in James Taylor (ed.), Selected writings of John Hughlings Jackson, 2 vols, London, Hodder and Stoughton, 1931-32. Reprinted New York, Basic Books, 1958, vol. 1, p. 52.

${ }^{132}$ Hughlings Jackson, op. cit., note 121 above, pp. 306-308.
} 


\section{Introduction}

explanations of disease. He stated, "It is rather difficult to define metaphysics. Some people call psychology metaphysics; some call anything very difficult and complex about mind and body metaphysics; some use it merely as a term of abuse." ${ }^{133}$ As an example of metaphysical explanations of disease he used the proposition that aphasic patients have lost words but not the memory of words. He said that, on the contrary, the words we speak and the words we think are the same thing; if not, mental words would be insubstantial. According to the law of conservation of energy, insubstantial phenomena cannot produce speech in any manner. He also lamented that medical students are not taught metaphysics, so they could be less metaphysical in their professional life. Saying that metaphysical explanations of hysteria explain nothing, he asserted that scientific physicians must steer clear of metaphysics. ${ }^{134}$

Hughlings Jackson took a dim view of materialism. In his third Croonian lecture he specifically disclaimed materialism, citing as sources a litany of scientists and writers including William Hamilton, John Stuart Mill, Herbert Spencer, Friedrich Max Müller, Alexander Bain, Thomas Henry Huxley, Emil Du Bois-Reymond, Thomas Laycock, John Tyndall and David Ferrier. ${ }^{135}$ These men, with whom Hughlings Jackson identified as scientific peers, include physicians and philosophers, professors and writers, and one or two figures who defy categorization.

In his April 1887 remarks on evolution and dissolution of the nervous system, he said that a critic of his Croonian lectures had accused him of fabricating the doctrine of concomitance in order to avoid the charge of materialism, and of appropriating Leibniz's "two-clock theory". He replied that this might be true but it does not matter, because Leibniz's philosophy is irrelevant to medicine. He added that evolutionists need not invoke supernatural agency to explain natural phenomena. He claimed that it is impossible to localize mental function because the nervous system is exclusively sensorimotor and reiterated his discussion of mind-body theories, saying that he could accept a mindbody identity theory if it meant that the nervous system has two functions, integration and thinking. Even if the mind-brain identity theory is right, the doctrine of concomitance as an artifice is still useful for physicians because it separates practical bedside diagnosis from non-localized psychological function. According to Hughlings Jackson, mental disease may be present but its nature excludes it from the purview of medical science.

\section{The Bibliography of John Hughlings Jackson}

The primary sources which contain Hughlings Jackson's writings are not widely held, and no published collection of his works exists. As an appendix to the published text of his 1903 Hughlings Jackson Lecture, Sir William Broadbent gave the only bibliography published during Hughlings Jackson's life. ${ }^{136}$ In 1931, Hughlings Jackson's student, collaborator, colleague and biographer James Taylor published the two-volume Selected

\footnotetext{
${ }^{133}$ J Hughlings Jackson, 'An address delivered at the opening of the section of pathology, at the annual meeting of the British Medical Association in Worcester, August 1882', Br Med J, 1882, ii: 305-308, p. 308.

${ }^{134}$ Ibid., p. 308.

${ }^{135}$ Hughlings Jackson, op. cit., note 31 above, p. 706.

${ }^{136}$ William Broadbent, 'Hughlings Jackson as a pioneer in nervous physiology and pathology', Brain, 1903, 26: 305-366, pp. 356-366.
} 


\section{Introduction}

writings of John Hughlings Jackson in collaboration with Gordon Holmes and Francis Walshe. ${ }^{137}$ The second volume of this set contains a bibliography which is more complete than Broadbent's. Careful study reveals that both Broadbent's and Taylor's bibliographies are incomplete and inaccurate. In his classic work on the early influences on the life and work of Hughlings Jackson, Samuel Greenblatt gives an account of Hughlings Jackson's signed works from 1861 to $1864 .{ }^{138}$ Greenblatt excludes unsigned papers, some of which were subsequently acknowledged by Hughlings Jackson and therefore can reliably be attributed to him.

We have compiled a complete catalogue raisonné of Hughlings Jackson's writings. We began by collecting all the articles mentioned in Broadbent, Taylor and Greenblatt. Comparing the articles to their entries in the published bibliographies, we found Greenblatt's bibliography to be accurate, though we were able to add several items. On the other hand, we found many inaccuracies in Broadbent and Taylor. Titles of some articles were incorrect, journal references were inaccurate, and some entries could not be found at the place cited. Additionally, careful comparison of papers cited as being published identically in several journals showed them to be, in fact, not identical.

We then examined the original periodicals in which these articles appeared, and collected other works not mentioned by the previous bibliographers. In examining our collection, we found internal references to a number of articles of which Hughlings Jackson claimed authorship, but which have no by-line. Having collected these items, we classified each article by date of publication and source periodical. We assigned each item a unique identification number, comprising the year of publication followed by the number of the item in that year in order of date of publication. If a paper was read on a certain date but published later, we used the date of publication as the assigned date. We treated each part of multiple-published lectures and papers as an individual article.

We found that some items tabulated as being Hughlings Jackson's personal writing are actually reports by unnamed third parties. These were often reports of lectures, or of Hughlings Jackson's comments at medical meetings. Therefore, we classified each paper by the type of by-line. We then assorted them into exclusive categories of bylined articles, case reports, letters, chapters in multi-authored textbooks, pamphlets, case reports under his care, unsigned editorials which he later claimed, and third person commentaries.

We found 537 articles by and about Hughlings Jackson published between 1861 and 1911. As might be expected, he published the majority of these papers between the ages of thirty and forty-five (1866-1880). He produced 352 by-lined articles, 78 cases under his care, 14 by-lined letters and 2 by-lined chapters in multi-authored texts. He wrote 4 unsigned editorials for which he later claimed authorship. Seventy-nine articles reported his lectures and opinions. We found 8 unsigned articles that he claimed elsewhere.

Virtually all the papers that we collected were written by Hughlings Jackson alone, but we found 18 which he wrote with a collaborator. Early in his career he wrote two papers with J Lockhart Clarke, in both of which Hughlings Jackson was the second author. He also published a case report in which Lockhart Clarke reported the pathological findings. Later

${ }^{137}$ Hughlings Jackson, op. cit., note 131 above.

${ }^{138}$ Greenblatt, op. cit., note 3 above, pp. 374-376. 
Table 3

Citations by source periodical

\begin{tabular}{|c|c|}
\hline Periodicals & Citations \\
\hline Medical Times and Gazette & 136 \\
\hline Lancet & 117 \\
\hline British Medical Journal & 104 \\
\hline Medical Press and Circular & 53 \\
\hline Brain & 33 \\
\hline Reports, Royal London Ophthalmic Hospital & 14 \\
\hline Medical Examiner & 11 \\
\hline London Medical Record & 10 \\
\hline $\begin{array}{l}\text { Transactions, Ophthalmological Society of the } \\
\text { United Kingdom }\end{array}$ & 8 \\
\hline Clinical Lectures and Reports. London Hospital & 7 \\
\hline Journal of Mental Science & 7 \\
\hline Proceedings, Medical Society of London & 7 \\
\hline West Riding Lunatic Asylum Medical Reports & 5 \\
\hline $\begin{array}{l}\text { Transactions, St Andrews Medical } \\
\text { Graduates' Association }\end{array}$ & 3 \\
\hline $\begin{array}{l}\text { Transactions of the International Medical } \\
\text { Congress. Seventh Session, } 1881\end{array}$ & 3 \\
\hline Medical Mirror & 2 \\
\hline The Polyclinic & 2 \\
\hline Reynolds System of Medicine & 2 \\
\hline Transactions, Clinical Society of London & 2 \\
\hline Edinburgh Medical Journal & 1 \\
\hline Illustrated Medical News & 1 \\
\hline Journal of Psychological Medicine and Mental Pathology & 1 \\
\hline London Hospital Gazette & 1 \\
\hline
\end{tabular}


Table 3 continued

\begin{tabular}{|l|c|}
\hline Periodicals & Citations \\
\hline Medical Record (NY) & 1 \\
\hline $\begin{array}{l}\text { Medico-Chirurgical Transactions. Royal } \\
\text { Medical and Chirurgical Society of London }\end{array}$ & 1 \\
\hline Ophthalmic Review & 1 \\
\hline The Popular Science Monthly & 1 \\
\hline La Revue Scientifique de la France et de l'Etranger & 1 \\
\hline Transactions, Medical Society of London & 537 \\
\hline Transactions of the Obstetrical Society & 1 \\
\hline Total & 1 \\
\hline
\end{tabular}

in his career he wrote three papers with his student and biographer James Taylor, once as the second author. He was the first author in papers with C E Beevor, J Galloway, J S Risien Russell, W S Colman, P Stewart, J S Collier, H D Singer, S Barnes and J Patton. Cases under his care were reported by R Atkinson and W H R Rivers. One case under the joint care of Hughlings Jackson and Morell Mackenzie was reported. Hughlings Jackson was first author of a 1900 letter to the editor of the Lancet, protesting the governance of the National Hospital for the Paralysed and Epileptic, which was signed by seventeen other physicians and surgeons including Gowers, Ferrier, Horsley and Marcus Gunn. ${ }^{139}$

Table 3 shows the distribution of Hughlings Jackson's writings according to the original source periodical.

Sixty-five per cent of Hughlings Jackson's output was published in the Medical Times and Gazette, the Lancet or the British Medical Journal; 81 per cent in these three and Medical Press and Circular and Brain. Two were published in New York journals, Popular Science Monthly and the Medical Record; one was published, in French, in La Revue Scientifique de la France et de l'Etranger.

Hughlings Jackson and Jonathan Hutchinson edited a by-lined column in the weekly Medical Times and Gazette entitled 'Reports of hospital practice in medicine and surgery', from 19 January 1861 to 3 January 1863 . This column contained reports of cases, under the care of various physicians, in London and provincial hospitals. Eleven of these case reports carry the initials JHJ, confirming Hughlings Jackson's authorship. Taylor names an additional nine case reports, two of which also appear in Broadbent, which carry no authorial identification other than appearing in a column under Hutchinson and Hughlings Jackson's joint by-line. Both Taylor and Broadbent knew Hughlings Jackson personally and would have had the opportunity to ask him whether he had written these disputed works. Unhappily, there is no record of such an event, and authorship of the disputed case reports remains

\footnotetext{
${ }^{139}$ J Hughlings Jackson, T Buzzard, R Brudenell Carter, et al., 'The medical staff and the management of the National Hospital for the Paralysed and Epileptic, Queen Square', Lancet, 1900, ii: 351-352.
} 


\section{Introduction}

unclear. We have therefore excluded these case reports from our catalogue because their authorship is uncertain.

We have identified 84 pieces not previously attributed to Hughlings Jackson by other bibliographers. These include by-lined letters, original articles and third person commentaries. Many of them describe his comments as president of the Ophthalmological Society of the United Kingdom and the Medical Society of London. They may be a rich source of information about how his works were received by wider medical audiences.

This catalogue raisonné of Hughlings Jackson's published writings includes virtually all his autograph work, excluding only a handful of letters to relatives which are in private hands. It also includes most of the writings about him and his ideas which appeared in British medical periodicals during his lifetime. Our bibliography also illuminates an aspect of Hughlings Jackson's personality which runs contrary to the portrait presented by his biographers. He is often portrayed as lonely, withdrawn, anti-social and modest beyond reason. However, at the zenith of his career he was a familiar figure at medical meetings in London and contributed to many of them. He was elected president of at least four medical societies. When the medical staff of the National Hospital made a public complaint about the governance of the hospital, he was the first signatory of the published letter of protest. He was willing to speak his mind, forcefully if necessary. His lifelong friend, Jonathan Hutchinson, reminds us that he was very much aware of his own intellectual gifts.

What emerges is a picture of a committed physician with few cultural interests but who enjoyed the company of other physicians. He was polite, humble and thoughtful, but was not given to expressions of false modesty. He would not have denied his own talents, such as intelligence or creativity. He was both professionally and intellectually ambitious, a trait which he never denied. Like many productive scientists, he was essentially benevolent in his later years, but we should not overlook his powerful commitment or determination to succeed both personally and professionally. 